\title{
PENERAPAN GUGATAN CLASS ACTION GUNA MENCAPAI ASAS SEDERHANA, CEPAT, DAN BIAYA RINGAN (STUDI KASUS DI LINGKUNGAN HIDUP)
}

\author{
Arista Candra Irawati \\ Dosen Fakultas Hukum Universitas Ngudi Waluyo \\ Email : acitujuhsatu@gmail.com
}

\begin{abstract}
Abstrak
Sistem hukum acara perdata Indonesia, yang dapat menjadi pihak dalam sengketa perdata antara lain manusia serta badan hukum melalui wakilnya/kuasa hukumnya. Pada tanggal 26 April 2002, Mahkamah Agung mengadakan suatu trobosan hukum baru dengan mengeluarkan PERMA No. 1 Tahun 2002. Penulis akan membahas permasalahan yang berkenaan dengan penerapan gugatan class action guna mencapai asas cepat, mudah dan biaya ringan (studi kasus di lingkungan hidup). Metode Penelitian yang digunakan yuridis normatif yang didukung data empiris dengan spesifikasi Penelitian deskriptif analisis. Analisa data yang digunakan analisa data kualitatif. Gugatan perwakilan kelompok adalah suatu tata cara pengajuan gugatan, dalam mana satu orang atau lebih yang mewakili kelompok mengajukan gugatan untuk diri atau diri mereka sendiri dan sekaligus mewakili sekelompok orang yang jumlahnya banyak, yang memiliki kesamaan fakta atau dasar hukum anatara wakil kelompok dan anggota kelompok dimaksud. Penerapan Class Action dalam lapangan hukum acara perdata mempunyai peranan yang sangat efektif dan efisien. Karena pihak Penggugat dan Tergugat hanya satu kali mengeluarkan biaya untuk berperkara. Tentunya hal ini akan menguntungkan kedua belah pihak dan dapat memenuhi asas biaya ringan dalam proses pengadilan sehingga mencapai asas peradilan cepat, sederhana dan biaya ringan.
\end{abstract}

Kata Kunci: Gugatan Class Action, Asas Peradilan, Lingkungan Hidup

\section{A. Pendahuluan}

Hukum Acara Perdata yang berlaku di Indonesia merupakan peninggalan zaman Hindia Belanda dan dalam suasana keterbelakangan bangsa Indonesia. Ketentuan Hukum Acara Perdata dimuat pada Reglement op de Burgerlijk Rechtsvordering $(R v)$, yang berlaku khusus untuk golongan Eropa, Stb. No. 52/1847, Herziene Inlandsche Reglement (HIR), yang diperuntukkan bagi golongan Bumiputera dan Timur Asing di Jawa Madura, Stb. No. 16 jo 57/1848, dan Rechtsreglement voor de Buitengewesten (Rbg.), sebagai pengganti peraturan 
yang berupa Reglemen yang tersebar dan berlaku hanya dalam suatu daerah tertentu seperti daerah Ambon, Aceh, Sumatra Barat, Palembang, Bali (untuk luar Jawa dan Madura), Stb. No. 227 tahun 1927. ${ }^{1}$

Sistem hukum acara perdata Indonesia, yang dapat menjadi pihak dalam sengketa perdata antara lain manusia ${ }^{2}$ serta badan hukum ${ }^{3}$ melalui wakilnya/kuasa hukumnya. Pihak-pihak yang berkepentingan dapat mengajukan gugatannya sendiri ke pengadilan untuk menuntut haknya atau dapat diwakilkan orang lain, atau bahkan harus diwakili oleh lain.

Gugatan yang diajukan secara perwakilan mempunyai dua makna yakni: 1) gugatan yang diajukan oleh atau terhadap badan hukum, yang diwakili oleh pengurusnya, serta gugatan yang diajukan oleh atau terhadap orang yang secara hukum tidak mempunyai kecakapan bertindak sendiri; 2) gugatan yang diajukan oleh seseorang kuasa hukum ke pengadilan untuk mewakili orang yang berkepentingan harus berdasarkan pada surat kuasa khsusus. Yang dimaksud dengan surat kuasa khusus menurut Pasal 1975 KUH Perdata adalah pemberian kuasa yang dilakukan hanya untuk satu kepentingan tertentu atau lebih. Di dalamnya biasanya dijelaskan mengenai tindakan-tindakan apa saja yang boleh dilakukan oleh penerima kuasa.

Dari kedua makna tersebut di atas, gugatan perwakilan dalam hukum acara perdata Indonesia hanya dapat diajukan: Pertama, apabila pihak yang berkepentingan mengajukan gugatan ke Pengadilan harus diwakili orang lain, ${ }^{4}$ dalam hal ini gugatan dapat dilakukan tanpa surat kuasa khusus dari pihak yang diwakili karena sudah ada penunjukkan pengadilan sedangkan; Kedua, apabila pihak yang diwakili tidak mau mengajukan sendiri ke Pengadilan karena atau karena ketidakmampuannya dalam beraca. Pada gugatan kedua ini hanya dapat dilakukan dengan surat kuasa. Lalu bagaimana jika terdapat kerugian yang timbul dan melibatkan ratusan orang? Jika melihat ketentuan dalam hukum acara perdata

\footnotetext{
${ }^{1}$ K. Wantjik Saleh, Hukum Acara Perdata (Jakarta: Ghalia, 1981), hlm. 15

${ }^{2}$ Pasal 118 HIR, 142 Rbg.

${ }^{3}$ Pasal 123 ayat (2) HIR, Pasal 147 ayat (2) Rbg., Pasal 6 No. 1 dan 3 serta Pasal 8 No. 2 Rv serta Pasal 1655 KUH Perdata).

${ }^{4}$ Contoh dalam kasus Badan Hukum Perseroang Terbatas (PT) harus diwakili oleh Direksi atau Anak yang masih di bawah perwalian walinya atau di bawah pengampuan oleh pengampunya.
} 
Indonesia hal ini sangatlah tidak mungkin. Bahkan asas peradilan sederhana, cepat dan biaya ringan tidak akan tercapai.

Untuk itu pada tanggal 26 April 2002, Mahkamah Agung mengadakan suatu trobosan hukum baru dengan mengeluarkan Peraturan Mahkamah Agung No. 1 Tahun 2002 tentang Acara Gugatan Perwakilan Kelompok (Class Action). PERMA ini diharapkan dapat menjadi dasar dan acuan para hakim dalam pemeriksaan gugatan di pengadilan. Sebelum adanya Peraturan MA ini sebetulnya sudah ada beberapa peraturan yang mengatur dan menjadi dasar hukum gugatan perwakilan yang biasa disebut Class Action. Salah satu undang-undang yang memuat aturan tentang class action adalah UU No. 23 Tahun 1997 tentang Pengelolaan Lingkungan Hidup sebagaimana telah diperbaharui dengan UU No. 32 Tahun 2009 tentang Perlindungan dan Pengelolaan Lingkungan Hidup.

Berdasarkan uraian tersebut, maka Penulis akan membahas permasalahan yang berkenaan dengan Penerapan Gugatan Class Action dengan perumusan masalah Bagaimana penerapan gugatan class action guna mencapai asas cepat, mudah dan biaya ringan (studi kasus di lingkungan hidup).

\section{B. Metode Penelitian}

Metode Penelitian yang digunakan dalam penelitian ini adalah yuridis normatif yang didukung data empiris, yaitu meneliti asas-asas hukum, kaedahkaedah hukum dan sistematika hukum. Penelitian mana dilakukan dengan cara meneliti kepustakaan yang berkaitan dengan gugatan Class Action untuk kemudian dikaitkan dengan data yang ada di lapangan guna memperoleh data sekunder. Untuk mendukung data sekunder dilakukan puka penelitian lapangan untuk memperoleh data primer, yakni data yang diperoleh langsung dari subjek penelitian dengan cara wawancara.

Spesifikasi Penelitian yang digunakan adalah deskriptif analisis yaitu yang menggambarkan peraturan perundang-undangan yang berlaku dikaitkan dengan teori-teori hukum dan praktik pelaksanaan hukum tertulis sehingga dapat menggambarkan pelaksanaan dan penerapan gugatan perwakilan kelompok (Class Action) dalam hukum acara perdata di Indonesia. Analisa data yang digunakan 
analisa data kualitatif, sehingga dapat memberikan gambaran secara rinci dan sistematis mengenai penerapan class action dalam praktik peradilan perdata.

\section{Hasil dan Pembahasan}

\section{Pengertian Gugatan Class Action}

Istilah Class Action berasal dari bahasa Inggris yakni penggabungan dua kata yakni class dan action. Maksud dari kata class adalah sekelompok orang, benda, kualitas atau kegiatan yang mempunyai kesamaan sifat atau ciri. Sedangkan pengertian action dalam dunia hukum adalah tuntutan yang diajukan ke Pengadilan.

Dari kedua arti istilah tersebut, maka Class Action diartikan sebagai penggambaran adanya sekelompok besar orang yang mempunyai kepentingan dalam suatu perkara tertentu, yang dapat terdiri dari satu atau lebih yang melakukan gugatan untuk mewakili kelompok besar orang tersebut tanpa harus menyebutkan satu persatu anggota kelompok yang diwakilinya.

Perwakilan ini semata-mata dilakukan bukan karena kelompok tersebut tidak dapat bertindak sendiri, melainkan karena terlalu banyaknya orang yang akan menggugat, sehingga harus diwakili agar tidak menimbulkan kesulitan administrasi pengadilan dan untuk kepentingan efisiensi dan efektifitas berperkara. Pengertian berkepentingan dalam prosedur Class Action ialah berkepentingan secara langsung, baik berkepentingan secara hukum maupun berkepentingan untuk suatu manfaat atau keuntungan atau kepentingan karena merasa dirugikan dan hendak menuntut pemulihan haknya sekaligus penggantian kerugian.

Dalam gugatan Class Action, seseorang atau lebih yang mengajukan gugatan ke Pengadilan mewakili kepentingan lainnya yang didasarkan pada kesamaan kepentingan serta adanya kesamaan masalah. Artinya ketika seseorang atau beberapa orang mengajukan gugatan ke Pengadilan dapat mengajukan gugatan untuk kepentingan sendiri sekaligus untuk kepentingan sekelompok orang, sebab kepentingan pihak yang mengajukan gugatan dengan pihak yang diwakili mempunyai kepentingan yang sama. 
Dari paparan di atas, maka dapat ditarik suatu pengertian gugatan perwakilan kelompok adalah suatu tata cara pengajuan gugatan, dalam mana satu orang atau lebih yang mewakili kelompok mengajukan gugatan untuk diri atau diri mereka sendiri dan sekaligus mewakili sekelompok orang yang jumlahnya banyak, yang memiliki kesamaan fakta atau dasar hukum anatara wakil kelompok dan anggota kelompok dimaksud.

\section{Asas Peradilan Sederhana, Cepat dan Biaya Ringan}

Asas peradilan sederhana, cepat dan biaya ringan diatur dalam UndangUndang No. 48 Tahun 2009 tentang Kekuasaan Kehakiman. UU ini menggantikan Undang-Undang Kehakiman sebelumnya yaitu Undang-Undang No. 4 Tahun 2004 tentang Perubahan atas Undang-Undang No. 14 Tahun 1970. Dalam Pasal 4 ayat (2) menyebutkan bahwa peradilan membantu pencari keadilan dan berusaha mengatasi segala hambatan dan rintangan guna mencapai peradilan sederhana, cepat dan biaya ringan. ${ }^{5}$

Dalam peraturan umum tidak dijumpai maksud dari pengertian asas peradilan sederhana cepat dan biaya ringan, namun dalam Undang-Undang Kekuasaan Kehakiman menyatakan bahwa asas yang mengatur mengenai keluhuran harkat martabat manusia terletak pada asas peradilan sederhana, cepat dan biaya ringan. Yang dimaksud dengan "sederhana" adalah pemeriksaan dan penyelesaian perkara dilakukan dengan cara efesien dan efektif. Sedang yang dimaksud dengan arti "biaya ringan" adalah biaya perkara yang dapat dijangkau oleh seluruh kalangan masyarakat. Namun demikian, untuk menegakkan asas ini dalam pemeriksaan dan penyelesaian suatu perkara tidaklah semata-mata mengesampingkan ketelitian dan kecermatan dalam mencari keadilan dan kebenaran yang sesungguhnya. ${ }^{6}$ Adapun yang dimaksud dengan cepat tidak dijumpai dalam penjelasan undang-undang tersebut. Untuk itu kata "cepat" dapat diukur menurut kelaziman yang dirasakan oleh masyarakat atas dasar perlakuan yang wajar dan yang seharusnya oleh para aparat penegak hukum. Seperi

\footnotetext{
${ }^{5}$ Bambang Waluyo, Pidana dan Pemidanaan (Jakarta: Sinar Grafika, 2002) hlm. 33

${ }^{6}$ Penjelasan Pasal 4 ayat (2) UU No. 48 Tahun 2009.
} 
misalnya terhadap suatu kasus, seorang polisi yang menerima pengaduan harus segera menyidik untuk kemudian dilimpahkan ke Kejaksaan. Selanjutnya jaksa akan segera melimpahkan dan menuntut agar Hakim segera untuk mengadili dan memutus tanpa adanya suatu penundaan waktu serta harus dengan rasa penuh tanggung jawab. ${ }^{7}$ Asas cepat ini berarti penyelesaian perkara dilakukan dengan segera tanpa memakan waktu yang terlampau lama. Peradilan cepat bukan untuk meminta hakim memeriksa dan memutus perkara peradilan dalam waktu satu jam atau bahkan setengah jam, melainkan maksud cepat disimi proses peradilan tidak memakan jangka waktu yang terlampau lama sampai bertahun-tahun sehingga asas kesederhaan pun tidak tercapai. ${ }^{8}$

Asas Peradilan sederhana, cepat dan biaya ringan apabila diterapkan dengan baik akan melahirkan suasana kenyamanan bagi masyarakat pencari keadilan. Setiap orang berhak atas pengakuan, jaminan, perlindungan dan kepastian hukum yang adil serta perlakuan yang sama didepan hukum (equality before the law). ${ }^{9}$ Keadilan merupakan suatu cita-cita yang irasional. Keadilan bukanlah sasaran pengetahuan, meskipun sangat diperlukan bagi kemauan dan tindakan manusia. Namun, jika dilihat dari sudut pandang pengetahuan rasional akan tampak adanya kepentingan atau konflik kepentingan. ${ }^{10}$ Tentunya dengan asas peradilan ini maka fungsi hukum dapat terlaksana sesuai dengan yang diharapkan. Fungsi Hukum sendiri untuk melindungi kepentingan manusia, untuk itu hukum yang sesungguhnya harus ditegakkan. Asas peradilan ini tidak hanya ditemukan di hukum acara perdata saja, melainkan juga diterapkan pada kasus-kasus pidana.

\footnotetext{
${ }^{7}$ Nia Sari Sihotang, Penerapan Asas Sederhana, Cepat Dan Biaya Ringan Di Pengadilan Negeri Pekanbaru Berdasarkan Undang-Undang Nomor 48 Tahun 2009 Tentang Kekuasaan Kehakiman, Jom Fakultas Hukum Volume III Nomor 2, Oktober 2016, hlm. 1-2

${ }^{8}$ A. Mukti Arto, Mencari Keadilan (Yogyakarta: Pustaka Pelajar, 2001), hlm. 67

${ }^{9}$ E. Sundari, Praktik Class Action di Indonesia (Yogyakarta: Cahaya Atma Pustaka, 2015), hlm. 3

${ }^{10}$ Hans Kelsen, Teori Umum tentang Hukum dan Negara (Bandung: Nusa Media \& Nuansa, 2006), hlm. 16
} 


\section{Penerapan Gugatan Class Action Guna Mencapai Asas Cepat, Mudah Dan Biaya Ringan (Studi Kasus Di Lingkungan Hidup)}

Penerapan Class Action dalam lapangan hukum acara perdata mempunyai peranan yang sangat efektif dan efisien. Mengapa demikian? Karena pihak Penggugat dan Tergugat hanya satu kali mengeluarkan biaya untuk berperkara. Tentunya hal ini akan menguntungkan kedua belah pihak dan dapat memenuhi asas biaya ringan dalam proses pengadilan.

Melalui gugatan Class Action ini, kendala dapat diatasi dengan cara saling menggabungkan diri bersama-sama dengan korban atau penderita yang lain dalam satu gugatan saja, yaitu gugatan kelompok. Gugatan Class Action ini juga dapat mencegah putusan-putusan yang berbeda dan tidak konsisten. Selain itu gugatan kelompok dapat melahirkan keadilan serta mengurangi hambatan-hambatan bagi Penggugat individual yang pada umumnya posisi mereka dalam posisi yang lemah. Dengan adanya gugatan Class Action ini akan mendorong setiap penanggung jawab suatu usaha atau kegiatan baik swasta maupun Pemerintah untuk selalu bertindak hati-hati.

Beberapa prosedur/kriteria agar gugatan Class Action dapat diterima: ${ }^{11}$

a. Dalam sistem hukum Anglo Saxon/Common Law (Amerika Serikat, Inggris, Australia dan Canada) gugatan Class Action akan diterima apabila satu orang atau lebih yang mewakili sejumlah orang, memiliki atau mengangkat masalah yang sama, baik mengenai hukum maupun fakta dan Class Action dapat diterapkan dalam bidang apa saja, bukan hanya untuk klaim di bidang lingkungan hidup saja, melainkan juga dalam bidang perlindungan konsumen dan Hak Asasi Manusia (HAM);

b. Menurut UU No. 32 Tahun 2009 tentang Perlindungan dan Pengelolaan Lingkungan Hidup dalam Bab XIII yang mengatur tentang penyelesaian sengketa lingkungan dalam Pasal 84 dijelaskan bahwa:

(1) Penyelesaian sengketa lingkungan hidup dapat ditempuh melalui pengadilan atau di luar pengadilan;

11 Mas Achmad Santosa, Seminar Prosedur Class Action dan Penerapannya, Jakarta, Kerjasama MARI-ICEI, HI, 2002, hlm. 13 
(2) Pilihan penyelesaian sengketa lingkungan hidup dilakukan secara sukarela oleh para pihak yang bersengketa;

(3) Gugatan melalui pengadilan hanya dapat ditempuh apabila upaya penyelesaian sengketa di luar pengadilan yang dipilih dinyatakan tidak berhasil oleh salah satu atau para pihak yang bersengketa.

Apabila melihat ketentuan dalam Pasal 84 khususnya ayat (2) yang menyatakan “....dilakukan secara sukarela oleh para pihak yang bersengketa”, kata para pihak menurut hemat Penulis mengandung arti bahwa penyelesaian sengketa lingkungan hidup dapat dilakukan dengan cara mengajukan gugatan kelompok (Class Action). Hal ini senada dengan Penjelasan Pasal tersebut bahwa ketentuan ini dimaksudkan untuk melindungi hak keperdataan para pihak yang bersengketa dan mencegah terjadinya putusan yang berbeda mengenai satu sengketa lingkungan hidup untuk menjamin kepastian hukum.

Ketentuan Pasal 84 UU No. 32 Tahun 2009 tersebut secara langsung menyebutkan bahwa gugatan kelompok menjadi salah satu sarana untuk menegakkan asas kepastian hukum.

Disamping kriteria-kriteris sebagaimana tersebut di atas, terdapat beberapa hal yang harus diperhatikan dan dipenuhi sebelum mengajukan gugatan Class Action yaitu:

1) Harus ada bukti yang kuat mengenai pertanggungjawaban Tergugat;

2) Jumlah total kerugian harus cukup besar;

3) Anggota kelas ataupun masalah dalam perkara yang akan diajukan seharusnya mewakili kepentingan umum.

Adanya aspek yang mendukung gugatan Class Action maka akan sangat efektif apabila diterapkan terhadap perkara dimana terdapat jumlah Penggugat yang begitu besar dan mempunyai kesamaan hukum maupun fakta dan tuntutan yang diderita atau dialami oleh Penggugat, akan tetapi yang harus diperhatikan dalam gugatan Class Action adalah pada saat anggota kelas akan mengambil keputusan untuk ikut serta dalam gugatan Class Action adanya suatu risiko yang mungkin timbul apabila gugatan Class Action ditolak. Anggota kelas dalam gugatan Class Action yang ditolak tersebut tidak dapat lagi mengajukan gugatan 
yang sama, baik secara individual maupun gugatan Class Action yang baru. Oleh sebab itu, pemilihan wakil kelas hatus dilakukan secara hati-hati dan wakil kelas adalah merupakan orang-orang yang dianggap memiliki bukti yang kuat dan mampu beracara di Pengadilan.

Penerapan gugatan class action ini dapat kita lihat dari contoh Perkara Nomor: 04/Pdt.G/2000/PNM yang diajukan oleh Abi Hasan Muan, Alfian, Amalubin, Sakurayati Trisna dan Amir Aswan. Seluruhnya adalah Penasehat Hukum pada Kantor Yayasan Lembaga Bantuan Hukum Indonesia (YLBHI) Bandar Lampung yang berdasarkan surat kuasa khusus tanggal 28 Januari 2000 selaku kuasa dari 27 orang yang mewakili 11 Desa (1145 Kepala Keluarga) yang berada di sekitar Daerah Aliran Sungai (DAS) Way Seputih Kabupaten Lampung Tengah, bertindak secara pribadi maupun mewakili masyarakat mengajukan gugatan perwakilan kelompok yang menggugat PT VE WONG BUDI INDONESIA, PT SINAR BAMBU MAS, dan PT BUDI ACID JAYA. Kasus ini dimaksudkan untuk melindungi kepentingan para pihak (para penggugat) sebagai tokoh masyarakat yang mempunyai masalah, fakta hukum, dan tuntutan yang sama yang bertempat tinggal di bantaran DAS Way Seputih yang mana mata pencaharian mereka adalah nelayan dimana para Penggugat merasa dirugikan akibat dari pencemaran DAS Way Seputih sehingga mengakibatkan berkurangnya pendapatan dan hilangnya mata pencaharian.

Saat itu, hakim dalam putusannya memberikan pertimbangan sebagai berikut: Menimbang bahwa dikarenakan Hukum Acara Perdata yang berlaku tidak mengenal prosedural Class Action, maka gugatan para Penggugat dinyatakan tidak dapat diterima. Berbeda halnya dengan Perkara Nomor: 83/Pdt.G/2002/PN.JKT.PST yang diajukan oleh Lembaga Bantuan Hukum (LBH) Jakarta yang bertindak untuk dan atas nama serta mewakili 15 orang sebagai wakil kelompok melawan Negara yang menggugat kerugian akibat bencana banjir. Bencana banjir yang dimaksud mengakibatkan kerugian yang tidak sedikit baik materiil maupun immateriil yang bersifat individual maupun komunal. Putusan perkara tersebut bahwa menimbang apa yang didalilkan tidak terbukti maka pertimbangan Hakim gugatan para Penggugat ditolak seluruhnya. 
Meskipun kedua perkara tersebut ditolak namun ada perbedaan alasan. Pada perkara pertama diajukan dengan Class Action tetapi karena belum ada suatu aturan yang khusus mengatur Class Action sehingga hukum acara yang dipakai adalah hukum acara perdata sehingga pengajuan gugatan sia-sia. Berbeda dengan perkara kedua yang digugat melalui gugatan perwakilan yang pada saat itu sudah berlaku Peraturan Mahkamah Agung No. 1 Tahun 2002. Sehingga gugatan diperiksa, diadili dan diputus dengan berpedoman pada PERMA tersebut. Hanya saja karena tidak terbukti mengenai fakta hukumnya maka putusan Hakim menyatakan menolak.

Dengan melihat dua kasus tersebut, menurut hemat Penulis adanya gugatan perwakilan yang berlaku saat ini memang sangat dibutuhkan. Hal ini guna untuk mencapai asas peradilan cepat, sederhana dan biaya ringan. Cepat dan sederhana tentunya karena gugatan Class Action akan menciptakan suasana peradilan yang efektif dan efisien dengan satu gugatan saja dapat memenuhi tuntutan sekelompok orang yang jumlahnya banyak. Selain itu, dengan gugatan perwakilan kelompok biaya yang akan ditanggung Penggugat akan semakin ringan dilain sisi apabila terjadi penggantian kerugian oleh Tergugat, biaya penggantiannya akan lebih mudah dan ringan.

\section{Simpulan}

Dalam gugatan Class Action, seseorang atau lebih yang mengajukan gugatan ke Pengadilan mewakili kepentingan lainnya yang didasarkan pada kesamaan kepentingan serta adanya kesamaan masalah. Artinya ketika seseorang atau beberapa orang mengajukan gugatan ke Pengadilan dapat mengajukan gugatan untuk kepentingan sendiri sekaligus untuk kepentingan sekelompok orang, sebab kepentingan pihak yang mengajukan gugatan dengan pihak yang diwakili mempunyai kepentingan yang sama. Pengertian gugatan perwakilan kelompok adalah suatu tata cara pengajuan gugatan, dalam mana satu orang atau lebih yang mewakili kelompok mengajukan gugatan untuk diri atau diri mereka sendiri dan sekaligus mewakili sekelompok orang yang jumlahnya banyak, yang 
memiliki kesamaan fakta atau dasar hukum anatara wakil kelompok dan anggota kelompok dimaksud.

Asas peradilan sederhana, cepat dan biaya ringan diatur dalam UndangUndang No. 48 Tahun 2009 tentang Kekuasaan Kehakiman. Dalam peraturan umum tidak dijumpai maksud dari pengertian asas peradilan sederhana cepat dan biaya ringan, namun dalam Undang-Undang Kekuasaan Kehakiman menyatakan bahwa asas yang mengatur mengenai keluhuran harkat martabat manusia terletak pada asas peradilan sederhana, cepat dan biaya ringan. Asas Peradilan sederhana, cepat dan biaya ringan apabila diterapkan dengan baik akan melahirkan suasana kenyamanan bagi masyarakat pencari keadilan. Setiap orang berhak atas pengakuan, jaminan, perlindungan dan kepastian hukum yang adil serta perlakuan yang sama didepan hukum (equality before the law).

Gugatan Class Action ini dapat mencegah putusan-putusan yang berbeda dan tidak konsisten. Gugatan Class Action ini akan mendorong setiap penanggung jawab suatu usaha atau kegiatan baik swasta maupun Pemerintah untuk selalu bertindak hati-hati.

Penerapan gugatan class action ini dapat kita lihat dari contoh Perkara Nomor: 04/Pdt.G/2000/PNM dan Perkara Nomor: 83/Pdt.G/2002/PN.JKT.PST Dari kedua perkara tersebut dapat dilihat bahwa pada kasus pertama diajukan dengan Class Action tetapi karena belum ada suatu aturan yang khusus mengatur Class Action sehingga hukum acara yang dipakai adalah hukum acara perdata sehingga pengajuan gugatan sia-sia. Berbeda dengan perkara kedua yang digugat melalui gugatan perwakilan yang pada saat itu sudah berlaku Peraturan Mahkamah Agung No. 1 Tahun 2002. Sehingga gugatan diperiksa, diadili dan diputus dengan berpedoman pada PERMA tersebut. Gugatan perwakilan kelompok merupakan salah satu cara untuk mencapai asas peradilan cepat, sederhana dan biaya ringan karena dapat secara langsung memenuhi seluruh tuntutan sekelompok orang dengan biaya yang relatif rendah. 


\section{DAFTAR PUSTAKA}

A. Mukti Arto, 2001, Mencari Keadilan, Yogyakarta: Pustaka Pelajar.

Bambang Waluyo, 2002, Pidana dan Pemidanaan, Jakarta: Sinar Grafika.

E. Sundari, 2015, Praktik Class Action di Indonesia,Yogyakarta: Cahaya Atma Pustaka.

Hans Kelsen, 2006, Teori Umum tentang Hukum dan Negara, Bandung: Nusa Media \& Nuansa.

K. Wantjik Saleh, 1981, Hukum Acara Perdata, Jakarta: Ghalia.

Mas Achmad Santosa, 2002, Seminar Prosedur Class Action dan Penerapannya, Jakarta, Kerjasama MARI-ICEI, HI.

Nia Sari Sihotang, Penerapan Asas Sederhana, Cepat Dan Biaya Ringan Di Pengadilan Negeri Pekanbaru Berdasarkan Undang-Undang Nomor 48 Tahun 2009 Tentang Kekuasaan Kehakiman, Jom Fakultas Hukum Volume III Nomor 2, Oktober 2016.

Putusan Perkara Nomor: 04/Pdt.G/2000/PNM

Putusan Perkara Nomor: 83/Pdt.G/2002/PN.JKT.PST

\section{Peraturan Peundang-Undangan}

Herziene Inlandsche Reglement (HIR)

Kitab Undang-Undang Hukum Perdata.

UU No. 32 Tahun 2009 tentang Perlindungan dan Pengelolaan Lingkungan Hidup.

Undang-Undang No. 48 Tahun 2009 tentang Kekuasaan Kehakiman

Peraturan Mahkamah Agung No. 1 Tahun 2002 tentang Acara Gugatan Perwakilan Kelompok (Class Action). 